\title{
Eye Bank
}

National Cancer Institute

\section{Source}

National Cancer Institute. Eye Bank. NCI Thesaurus. Code C133320.

A facility whose operations include collection, processing and distribution of ocular tissues. 